\title{
Central Indian tectonics revisited using aeromagnetic data
}

\author{
Mita Rajaram and S. P. Anand \\ Indian Institute of Geomagnetism, Colaba, Mumbai 400 005, India \\ (Received December 27, 2002; Revised March 6, 2003; Accepted March 31, 2003)
}

\begin{abstract}
Aeromagnetic data, covering $600,000 \mathrm{~km}^{2}$ of Central India, have been analysed for the first time to throw light on the various tectonic blocks of the region, ranging in age from the Archean to the present. Existing geotectonic models are based on inadequate data and studies of relatively small regions. From the aeromagnetic data, we use the analytic signal and Euler deconvolution, to elucidate the subsurface structure of the region and redefine the tectonic elements. Contrary to the belief that the Central Indian shear defines the edge of the Central Indian craton, we find that the Sukinda thrust merges with the Tan shear to demarcate the edge of the Bastar and Eastern Ghat blocks by a shear that extends for approximately $1000 \mathrm{~km}$ in length. We call this the Main Peninsular shear. Magnetic anomaly data can thus play a crucial role in understanding the tectonic elements of a region with large surface cover.
\end{abstract}

Key words: Aeromagnetic anomalies, analytic signal, Euler solutions, Peninsular India, Tectonic elements.

\section{Introduction}

The Central Indian zone under study includes three Archean cratons, two Gondwana basins, Proterozoic mobile belts and basins interspersed with Phanerozoic cover. Existing geotectonic models have been based on detailed studies of relatively small segments or on intensive reliance on limited disciplines like gravity or geology (Sarkar, 2001). Further more the surface cover (sediments and traps) complicates the interpretation. Our knowledge is rudimentary because of the paucity of geologic data in the Central Indian zone and the Eastern Ghat Mobile belt (Sarkar, 2001). To construct coherent and realistic models it is necessary to synthesise data from large areas and it is in this regard that for a given region aeromagnetic and gravity data can prove useful. However the available gravity map series of India (NGRI, 1975) are based on data collected on the ground, hence the station distribution is dictated by road access resulting in some large data gaps. The aeromagnetic data available for purchase from the Geological Survey of India (GSI), is collected at a flight line spacing of $4 \mathrm{~km}$ and is the only data set that has a fairly uniform and complete data coverage and can thus provide a coherent view in reconstructing the tectonic evolution of the region. Analysis of aeromagnetic data over this large region $\left(>600,000 \mathrm{~km}^{2}\right)$ has not previously been attempted. In this study we demonstrate that quantitative analysis of magnetic data delineates geotectonic blocks of the region independent of surface cover.

\section{Geology and Tectonics of the Region}

The study area lies between $17^{\circ}$ to $24^{\circ} \mathrm{N}, 78^{\circ}$ to $88^{\circ} \mathrm{E}$ and a simplified geology map (Sarkar, 2001) with main tectonic elements (GSI, 2000) is shown in Fig. 1. The Bastar craton $[\mathrm{BB}]$ is separated from the Dharwar [DB] and Singhbhum cratons [SB] by the Godavari $[\mathrm{GG}]$ and Mahanadi $[\mathrm{MG}]$

Copy right(C) The Society of Geomagnetism and Earth, Planetary and Space Science (SGEPSS); The Seismological Society of Japan; The Volcanological Society of Japan; The Geodetic Society of Japan; The Japanese Society for Planetary Sciences.
Gondwana grabens respectively; with the Eastern Ghat Mobile belts [EGMB] lying to the south east. From detailed geological, petrological and structural studies the Central Indian shear (CIS, Yedekar et al., 1990) has been identified, which separates the Bastar block from the northern (Bundelkhand) block. The western side of this shear is buried under alluvium and traps while to the east it forks into two parts with the northern part coming close to the Tan shear. From geological and geochronological data the other arm is conjectured to extend eastwards below the Gondwana sediments and merge with the Singhbhum shear [8] (Yedekar et $a l ., 1990)$. The Tan shear [3] is believed to extend below the cover (Yedekar et al., 1990) and possibly joins the Barabhum shear [7] within the Singhbhum block [SB]. Due to the extensive surface cover of the Mahanadi Graben [MG] by the Gondwana sediments, the subsurface extension of these structures needs to be verified. The north-western part of the study region and the northern part of the Godavari Graben are covered by Deccan flood basalts. The Bastar craton consists of two Proterozoic basins (Chattisgarh [C] and Indravati [I]). The Central Indian Tectonic zone (CITZ) (Yedekar et al., 1990) lying to the north of the CIS is marked by several sub-parallel ENE trending faults: Narmada North and South [11 and 12], Tapti fault [1], Gavilgarh fault [2], Tan shear [3], Bamni-Chilpa fault [5] and Tatapani fault [6]. The Tatapani area has several thermal springs that are responsible for the high heat flow in Central India (Ravi Shankar, 1991).

The Singhbhum Block [SB] to the east is separated from the rest of the Indian Peninsular Shield by the Mahanadi Graben $[\mathrm{MG}]$ occurring to its west and the Sukinda thrust (Mahadevan, 2001) to the south. Tectonically, this block includes the Singhbhum granite (which includes banded iron formation) to the south, and the Proterozoic Singhbhum mobile belt in the middle separated from the Chotanagpur Granite Gneiss terrain in the north by the Barabhum shear [7]. The Eastern Ghat Mobile Belt (EGMB) is a high-grade NE-SW metamorphic belt to the south of the Singhbhum block. The 


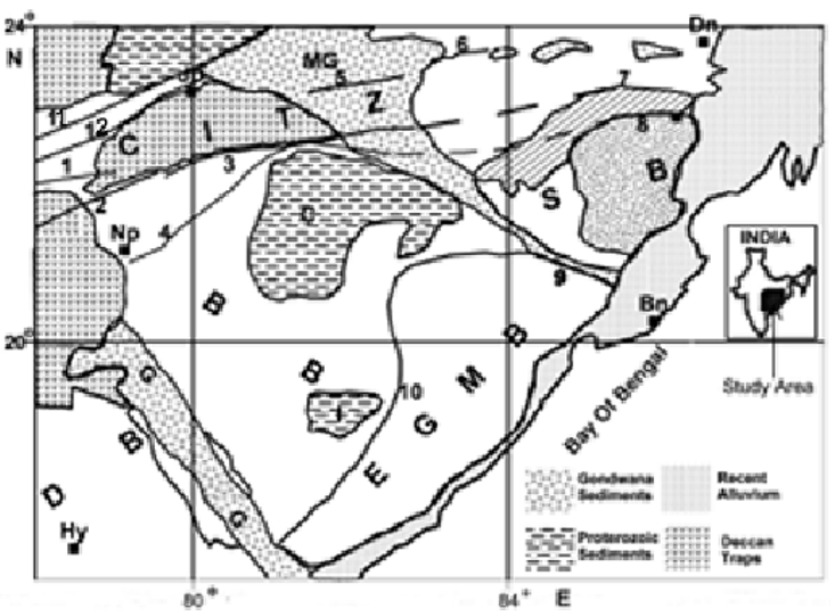

Fig. 1. Simplified geology and tectonic map of the study area redrawn from Sarkar (2001) and GSI (2000). DB-Dharwar block, BB-Bastar block, SB-Singhbhum block, CITZ-Central Indian Tectonic zone, EGMB-Eastern Ghat Mobile Belt, GG-Godavari graben, MG-Mahanad graben, I-Indravati basin, C-Chattisgarh basin, 1-Tapti fault, 2-Gavilgarh fault, 3-Tan shear, 4-Central Indian shear, 5-Bamni-Chilpa fault, 6-Tatapani fault, 7-Barabhum shear, 8-Singhbhum shear, 9-Sukinda thrust, 10-Sileru shear, 11-North Narmada fault, 12-South Narmada fault. Hy-Hyderabad, Bn-Bhubhaneswar, Dn-Dhanbad, Jb-Jabalpur, Np-Nagpur.

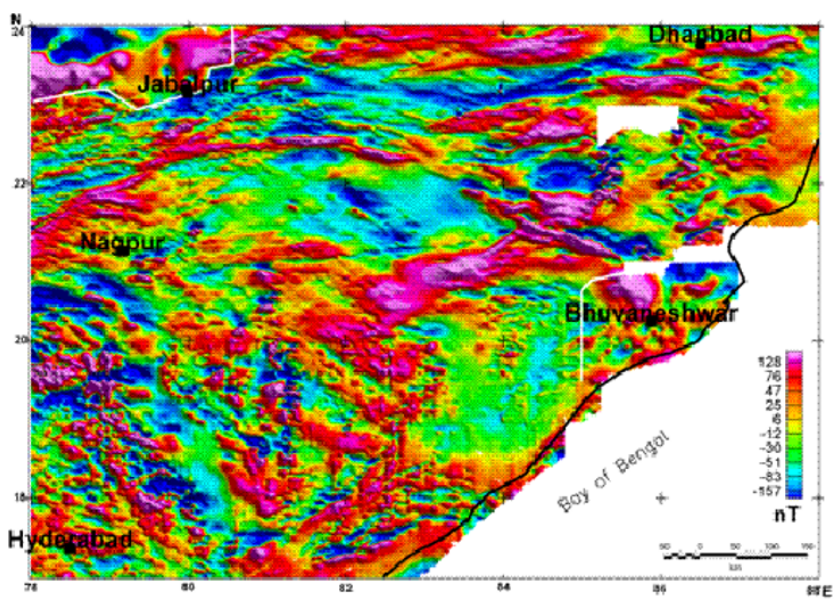

Fig. 2. Image map of the aeromagnetic anomalies. White line demarcates region of ground data included (Anand et al., 2002; Mishra et al., 1996).

EGMB is separated from the adjoining blocks by a major shear/thrust called Sileru shear zone [8].

\section{Aeromagnetic Data Analysis and Discussion}

Aeromagnetic data (GSI, 1995) for the area $17^{\circ}$ to $24^{\circ} \mathrm{N}$, $78^{\circ}$ to $88^{\circ} \mathrm{E}$ collected in the period $1983-1992$ at a terrain clearance of $5000 / 7000 \mathrm{ft}$, with NS oriented flight lines and $4 \mathrm{~km}$ flight line spacing, were purchased from GSI, as analogue degree sheet maps. Data collected in the period 197879 over parts of the Narmada Sone region at a flight altitude of $3500 \mathrm{ft}$ and line spacing of $2 \mathrm{~km}$ are also included. These maps were machine digitized along contours, corrected for the main geomagnetic field, gridded at $2 \mathrm{~km}$ interval reduced to a common altitude of $5000 \mathrm{ft}$ and merged. A grid interval of less than $2 \mathrm{~km}$ (related to Nyquist frequency) is likely to give some spurious results. Preparation of an accurate crustal

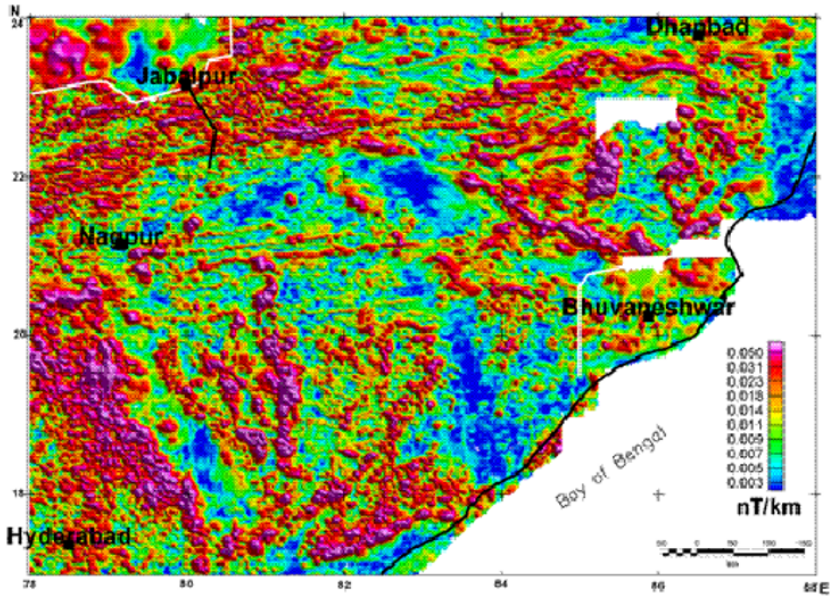

Fig. 3. Analytic signal map. Analytic signal maxima are located over magnetic source edges. MT profile near Jabalpur superposed

anomaly map is very crucial for any meaningful interpretation. Some results for the region from $17^{\circ}$ to $20^{\circ} \mathrm{N}, 78^{\circ}$ to $84^{\circ} \mathrm{E}$ have been reported (Anand and Rajaram, 2003), but to appreciate the regional tectonics, it is necessary to look at the region in entirety. The magnetic anomaly map obtained (Geosoft, 1999) is shown in Fig. 2. Published ground magnetic data continued to $5000 \mathrm{ft}$ have been used to fill the data gaps in the Mahanadi area to the southeast (Anand et $a l ., 2002$ ) and the northwest region in the CITZ (Mishra et $a l ., 1996)$. These areas are included only to check the continuity of features and are separated from the aeromagnetic data by a white line. A very striking feature of this map is the arcuate shaped high cutting across the Central Indian region from west to east. From ground magnetic data (Anand et al., 2002) it is clear that this trend runs across the Mahanadi coastal basin and continues to the Bay of Bengal. The magnetic anomaly trends are in conformity with the known structural trends of the various tectonic blocks. The NWSE Dharwarian trends appear to dominate the Dharwar and Bastar craton changing dramatically to NE-SW within the EGMB that ends at the Sukinda thrust [9]. Trends within the Singhbhum region are dominantly E-W.

The changing inclination $\left(20^{\circ}<I<35^{\circ}\right)$ of the geomagnetic field makes it difficult to identify the magnetic sources directly from the anomalies. We therefore calculate the analytic signal (Roest et al., 1992) wherein the maxima outline the edges of magnetic sources. Figure 3 depicts the analytic signal map of the region. The most striking feature in this map is again an analytic signal maxima related to the arcuate shaped magnetic high identified above. On close examination with the mapped shears and faults, we find that the Gavilgarh fault [2], part of the Tan shear [3], the western edge of the Mahanadi basin [MG] and the Sukinda thrust [9] merge in the subsurface to form this long and continuous high. The signature of the mapped Central Indian shear [6] is very weak. In the northwest part of the map, areas of significant analytic signal maxima are bounded to the south by the Gavilgarh fault [2] and Tan shear [3], to the east by the western margin of the Mahanadi Gondwana Graben [MG] and to the north by the Tapti fault [1]. Many of these sources are related to the Deccan traps on comparison with Fig. 1. 


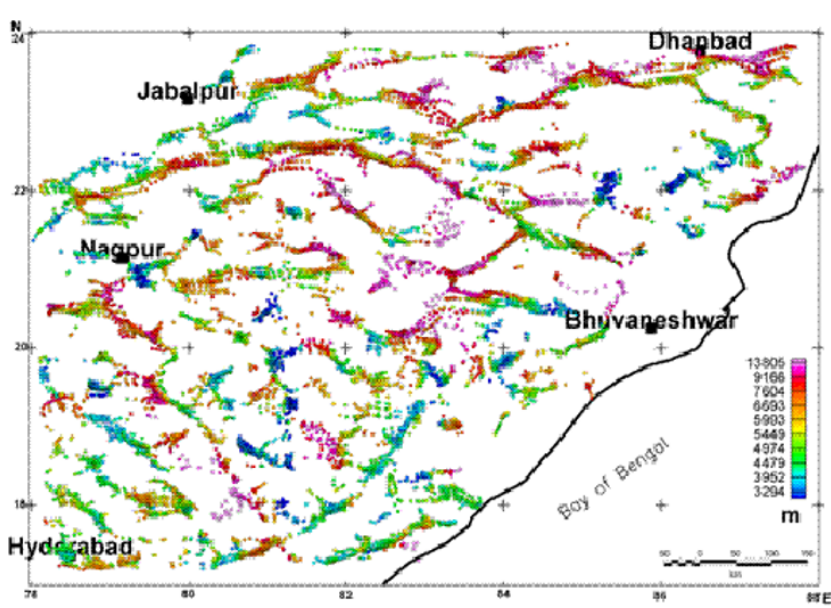

Fig. 4. Magnetic source depths and locations using Euler deconvolution. (window length $=10$ and structural index $=2$ ). Depth below ground level.

We also infer that the Narmada Sone region (between the $\mathrm{N}$ and S Narmada faults) [11 and 12] up to the Mahanadi Graben [MG] covered by alluvium are underlain by traps. The Godavari Graben [GG], the Chattisgarh basin [C] and the northern block of the Eastern Ghats [EGMB] are devoid of magnetic sources. Two parallel trends of analytic signal maxima running E-W across the Bastar craton (east of Nagpur) evident on this map can possibly be related to systems of dykes. The northern edge of the Singhbhum block [SB] is also clearly defined and the highs related to the Singhbhum iron ore are also evident.

Euler deconvolution helps to determine the position, depth and nature of any sources present in the magnetic data (Reid et al., 1990). We calculated Euler solutions of the aeromagnetic anomalies gridded at $2 \mathrm{~km}$ and $5 \mathrm{~km}$ intervals, in the study region for different structural indices $(S I=0,0.5$, $0.75,1,1.5,2$ and 3 ) with depth uncertainty set to a maximum of $15 \%$. The results were very consistent in locating the position of the sources although the scatter of the solutions varied. Figure 4 is a plot of the Euler solutions gridded at $5 \mathrm{~km}$ interval for an $S I$ of 2 . The most striking feature again is the long arcuate shaped feature running across the region for around $1000 \mathrm{~km}$ from west to east forming one major shear marking the edge of the Eastern Ghat block [EGMB], the Bastar craton [BB] and possibly the Dharwar craton [DB] to the west. We call this shear the Main Peninsular shear. It is interesting to note that in the region where no fault has been mapped between the Tan shear [3] and the Sukinda thrust [9] the Euler solutions are very deep, indicating sources down-faulted beneath the Gondwana sediments. The presence of extensive surface cover is possibly responsible for this part of the fault/shear not having any surface expression and the conjecture that the Tan shear extends below the Gondwanas into the Barabhum shear. The Singhbhum block stands out as a separate block with its edge being defined by the Main Peninsular shear to the south and west and the NE-SW trending shear that merges with the Barabhum shear [7]. The CIS [4] comes close to the Tan shear [3] and appears to turn around and continues as a NW-SE shear within the Chattisgarh basin.

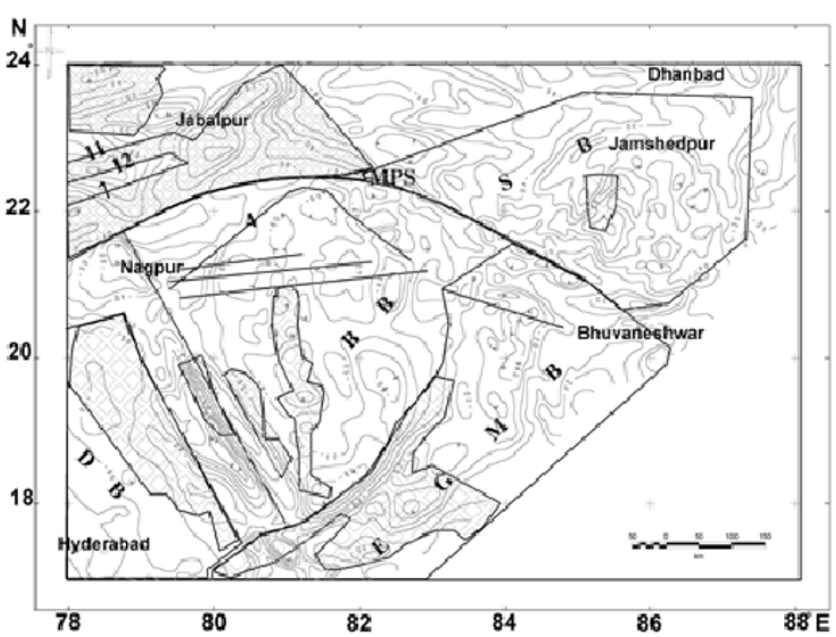

Fig. 5. Schematic representation of interpreted tectonic blocks and magnetic sources (hatched) from the present analysis superposed on the Bouguer gravity anomaly (NGRI, 1975). Contour interval 10 mgals. MPS-Main Peninsular shear and other symbols are as in Fig. 1.

\section{Conclusion}

From the analysis of the aeromagnetic data we have identified the Main Peninsular shear as a single shear defining the northern limit of the Bastar craton and EGMB though its surface manifestation is a conglomerate of several separate faults or shears. Figure 5 schematically represents tectonic blocks and magnetic sources as interpreted from the present analysis. In the gravity data, the presence of the Jabalpur gravity high (Verma and Banerjee, 1992) and the uneven/scarce data distribution in this area (NGRI, 1975) has distorted the picture and therefore the gravity anomaly so far has not explicitly identified this shear. Superposition of the interpreted tectonic blocks derived from the aeromagnetic data on the gravity map (NGRI, 1975) depicts a very good match between the two (Fig. 5). From the gravity map (NGRI, 1975; Verma and Banerjee, 1992), it is clear that the shear extends further westwards. The MT data over the Jabalpur Mandla profile (location shown in Fig. 3) depicts a high resistive body (granite) whose thickness increases significantly (Gokarn et al., 2001) south of the Main Peninsular shear. We believe this is due to the change in tectonic blocks reflected in the aeromagnetic picture.

It is thus clear that a paucity of data coverage and the masking effects of surface cover can hinder interpretation. Aeromagnetic data overcome both of these handicaps and result in a reliable interpretation. Aeromagnetic data have not been collected to the west of the study region due to trap cover. However, this data, if collected should provide very valuable inputs to the present study. There is an urgent need for aeromagnetic coverage of continental areas to help reconstruct the tectonic evolution on a global basis.

\section{References}

Anand, S. P. and M. Rajaram, Study of Aeromagnetic data over part of Eastern Ghat Mobile Belt and Bastar craton, Gondwana Research, 2003 (communicated)

Anand, S. P., V. C. Erram, and M. Rajaram, Crustal structure delineation of Mahanadi basin from ground magnetic survey, J. Geol. Soc. India, 60 283-291, 2002.

Geological Survey of India, Catalogue of Aero-Geophysical Maps, Airborne 
Mineral Surveys and Exploration Wing, Bangalore, India, 1995.

Geological Survey of India, Seismo Tectonic Atlas of India and its Environs, 2000.

Geosoft, Oasis Montage Data Processing and Analysis (DPA) systems for Earth Science applications (ver.4.3), Geosoft Inc., 1999.

Gokarn, S. G., C. K. Rao, G. Gupta, B. P. Singh, and M. Yamashita, Deep Crustal structure in the Central India from Magnetotelluric studies, Geophys. J. Int., 144, 685-694, 2001.

Mahadevan, T. M., Geology of Bihar and Jharkhand, 563 pp., Text Book Series, Geol. Soc. India, 2001.

Mishra, D. C., S. B. Gupta, M. B. S. V. Rao, and M. Venkatrayudu, Crustal structure and basement tectonics under Vindhyan Basin: Gravity and Magnetic study, Mem. Geol. Soc. India, 36, 213-224, 1996.

NGRI/GPH-2, Bouguer Gravity Anomaly Map of India, 1:5 million scale, 1975.

Ravi Shankar, Thermal and Crustal Structure of Sonata-a zone of midcontinental rifting in Indian Shield, J. Geol. Soc. India, 37, 211-220,
1991.

Reid, A. B., J. M. Allsop, H. Granser, A. J. Millett, and W. I. Somerton, Magnetic interpretation in three dimensions using Euler deconvolution, Geophysics, 55, 80-91, 1990.

Roest, W. R., J. Verhoef, and M. Pilkington, Magnetic interpretation using the 3D analytical signal, Geophysics, 57, 116-125, 1992.

Sarkar, A. N., Explanatory brochure on the Tectonic map of India, Geological Survey of India, 2001.

Verma, R. K. and P. Banerjee, Nature of Continental Crust along the Narmada-Son Lineament inferred from Gravity and Deep Seismic Sounding Data, Tectonophysics, 202, 375-397, 1992.

Yedekar, D. B., S. C. Jain, K. K. K. Nair, and K. K. D. Dutta, The Central Indian collision suture, Geol. Survey India, Spl. Publication, 28, 1-43, 1990.

M. Rajaram (e-mail: mita@iig.iigm.res.in) and S. P. Anand 